\title{
INCREASE OF GLYCOSAMINOGLYCANS AND METALLOPROTEINASES 2 AND 9 IN LIVER EXTRACELLULAR MATRIX ON EARLY STAGES OF EXTRAHEPATIC CHOLESTASIS
}

\author{
Pedro Luiz Rodrigues GUEDES', Maria Christina Marques Nogueira CASTAÑON², \\ Márcia Regina NAGAOKA ${ }^{3}$ and Jair Adriano Kopke de AGUIAR ${ }^{1}$
}

\begin{abstract}
Context - Cholestasis produces hepatocellular injury, leukocyte infiltration, ductular cells proliferation and fibrosis of liver parenchyma by extracellular matrix replacement. Objective - Analyze bile duct ligation effect upon glycosaminoglycans content and matrix metalloproteinase (MMPs) activities. Methods - Animals (6-8 weeks; $\mathrm{n}=40$ ) were euthanized 2, 7 or 14 days after bile duct ligation or Sham-surgery. Disease evolution was analyzed by body and liver weight, seric direct bilirubin, globulins, gamma glutamyl transpeptidase (GGT), alkaline phosphatase (Alk-P), alanine and aspartate aminotransferases (ALT and AST), tissue myeloperoxidase and MMP-9, pro MMP-2 and MMP-2 activities, histopathology and glycosaminoglycans content. Results - Cholestasis caused cellular damage with elevation of globulins, GGT, Alk-P, ALT, AST. There was neutrophil infiltration observed by the increasing of myeloperoxidase activity on $7(P=0.0064)$ and $14(P=0.0002)$ groups which leads to the magnification of tissue injuries. Bile duct ligation increased pro-MMP-2 $(P=0.0667)$ MMP-2 $(P=0.0003)$ and MMP-9 $(P<0.0001)$ activities on 14 days indicating matrix remodeling and establishment of inflammatory process. Bile duct ligation animals showed an increasing on dermatan sulfate and/or heparan sulfate content reflecting extracellular matrix production and growing mitosis due to parenchyma depletion. Conclusion Cholestasis led to many changes on rats' liver parenchyma, as so as on its extracellular matrix, with major alterations on MMPs activities and glycosaminoglycans content.
\end{abstract}

HEADINGS - Extrahepatic cholestasis. Glycosaminoglycans. Matrix metalloproteinases.

\section{INTRODUCTION}

On 2012, in Brazil, hepatic diseases of many etiologies caused almost 250 '000 hospital internalizations, with over 2'000 deaths, burdening Brazilian government in over 500 million reais ${ }^{(6)}$. During chronic stages a massive substitution of liver parenchyma by scar tissue occurs, causing hepatic fibrosis, which is the common endpoint for most types of chronic liver injury, considered an irreversible process ${ }^{(31)}$. There are many causes of chronic liver inflammation that invariably gives rise to tissue fibrosis, which can be considered a deregulated fibroproliferative response ultimately affecting tissue architecture and function because of extracellular matrix (ECM) accumulation ${ }^{(42)}$.

A widespread experimental model for liver injury is carbon tetrachloride $\left(\mathrm{CCl}_{4}\right)$ injection which causes transitory effects such as loss of $\mathrm{Ca}^{2+}$ homeostasis, lipid peroxidation, toxin release and apoptotic events followed up by tissue regeneration ${ }^{(18,27,29)}$. Although, this solvent may cause unspecific toxicity, including central nervous system depletion, respiratory failure and death ${ }^{(3)}$, and animal response to $\mathrm{CCl}_{4}$ is variable, with high mortality taxes besides the long period to induce cirrhosis ( 8 to 12 weeks). Beyond that, nowadays, human $\mathrm{CCl}_{4}$ intoxication is very rare ${ }^{(28)}$.

Extrahepatic cholestasis induction is an alternative to study liver fibrosis, where morphological changes similar to human biliary cirrhosis occur without needing of pathology process activation by any exogenous toxin. Cholestasis results on high concentrations of biliary salts in hepatocytes, inducing hepatocellular death by apoptosis ${ }^{(12,21,34,35)}$. Common bile duct ligation (BDL) have been used to induce extrahepatic cholestasis on rats, promoting liver injury, intra-hepatic epithelial biliary cells proliferation, myofibroblastic differentiation of hepatic stellate cells (HSCs) and ECM deposition ${ }^{(8,39)}$.

Current treatment of liver fibrosis is limited to withdrawal of the agent, but it is not always feasible. Therefore, it is important to establish disease's pathway to figure out targets to liver recover ${ }^{(2)}$. The aim of this study was to comprehend cholestatic liver disease by analyzing changes on hepatic parenchyma and ECM.

\footnotetext{
Declared conflict of interest of all authors: none

'Departamento de Bioquímica, Universidade Federal de Juiz de Fora - UFJF, Juiz de Fora, MG: ${ }^{2}$ Departamento de Morfologia, UFJF; ${ }^{3}$ Departamento de Biociências, Universidade Federal de São Paulo - UNIFESP (Baixada Santista), Santos, SP. Brasil.

Correspondence: Jair Adriano Kopke de Aguiar. Universidade Federal de Juiz de Fora. Rua José Lourenço Kelmer, s/n - Campus Universitário Bairro São Pedro - CEP
} 36036-900. Juiz de Fora, MG, Brasil. E-mail: jair.aguiar@ufjf.edu.br 


\section{METHODS}

\section{Materials}

Ketamine 10\% (Syntec, Cotia, SP, Brazil); Xylazine 2\% (Syntec, Cotia, SP, Brazil); Nylon 5-0 suture lines (Shalon, Sao Luis M. Belos, GO, Brazil); Catgut 5-0 suture lines (Technofio, Goiania, GO, Brazil); Biochemical diagnosis kits (LabtestDiagnostica, Lagoa Santa, MG, Brazil); Cetyltrimethylammonium bromide (CTAB, Sigma-Aldrich Co., St. Louis, MO, USA); $o$-dianisidine hydrochloride (Sigma-Aldrich Co., St. Louis, MO, USA); Acrylamide (Ludwig Biotechnology Ltd., Porto Alegre, RS, Brazil); N,N'-methylenebisacrylamide (Neon Comercial Ltda., São Paulo, SP, Brazil); Tris(hydroxymethyl)aminomethane (BiosolveValkenswaard, Netherlands); Triton x-100 (Vetec Fine Chemicals Ltda., Duque de Caxias, RJ, Brazil); Gelatin (Sigma-Aldrich Co., St. Louis, MO, USA); Papain from papaya latex (Sigma-Aldrich Co, St Louis, MO, USA); $Q$-sepharose fast flow anion exchange resin (GE Healthcare Life Sciences, Uppsala, Sweden).

\section{Animals}

We used 6 to 8 weeks old male Wistar rats $(n=40)$ with four animals kept on each plastic cage for 3 days before surgical procedure. All animals were housed in a room maintained at $23 \pm 1{ }^{\circ} \mathrm{C}$ with $12 \mathrm{~h}$ light/dark cycles and had free access to standard chow and tap water. The Animal Experiments Committee of Federal University of Juiz de Fora approved this study according to the "Guide for the Care and Use of Laboratory Animals" (protocol number 025/2013).

\section{Common bile duct ligation}

All surgical procedures were performed under intraperitoneally ketamine $(90 \mathrm{mg} / \mathrm{kg})$ and xylazine $(10 \mathrm{mg} / \mathrm{kg})$ anesthesia with clean surgical techniques as previously described ${ }^{(7,31)}$. Briefly, obstructive jaundice was induced by midline laparotomy and common bile duct exposure followed by double ligation and section between stitches. Sham-operated animals were submitted to a similar procedure, without BDL. After surgery, BDL $(n=25)$ and Sham-operated $(n=15)$ animals were randomly divided in 3 groups with different induction time (2, 7 or 14 days), being euthanized by deep anesthesia (ketamine $180 \mathrm{mg} / \mathrm{kg}$ ) and exsanguination by the end of the experiment.

\section{Biochemical analysis}

During euthanasia, blood was drawn by infrahepatic inferior vena cava puncture in test tubes and serum obtained by centrifugation, frozen and kept at $-80^{\circ} \mathrm{C}$ until analysis. Serum levels of aspartate aminotransferase (AST), alanine aminotransferase (ALT), alkaline phosphatase (Alk-P), $\gamma$-glutamyl transpeptidase (GGT), direct bilirubin (DB) and globulins were measure by automated standardized colorimetric procedures using a Labmax 240 analyzer (LabtestDiagnóstica, Brazil), in accordance with technical manual.

\section{Histopathological examination}

Excised liver specimens were fixed in formalin $(10 \%$ on PBS 0.05 M pH 7.4) and embedded with paraffin. Hematoxylin and Eosin (H\&E) staining was performed according to standard procedures. For morphometric analysis, we used image analyzer Axiovision version 4.5 (Zeiss, Germany).

\section{Gelatinase zymography}

Activities of matrix metalloproteinase (MMP) pro MMP-2, MMP-2 and MMP-9 were measured as previously described ${ }^{(26,37)}$. Briefly, liver homogenates were prepared with electrophoresis loading buffer and sacccharose $0.25 \mathrm{M}$. Thereafter, samples were subjected to electrophoresis on $10 \%$ sodium dodecyl sulfate-polyacrylamide gel electrophoresis (SDS-PAGE) with copolymerized gelatin $(2 \mathrm{mg} / \mathrm{mL}$; Sigma-Aldrich Co., St. Louis, MO, EUA). After electrophoresis, gels were washed with $2 \%$ Triton X-100 for $1 \mathrm{~h}$ (3 times, 20 min each) and incubated for $24 \mathrm{~h}$ in enzyme assay buffer (50 mM Tris- $\mathrm{HCl}, \mathrm{pH} 8.2,5 \mathrm{mM} \mathrm{CaCl}_{2}$ and $1 \mu \mathrm{M} \mathrm{ZnCl}_{2}$ ) to enzymatic activity bands development. After incubation, gels were fixed and stained in $40 \%$ methanol, $10 \%$ acetic acid and $0.1 \%$ (wt./v) Coomassie Blue R-250 for $1 \mathrm{~h}$, and then unstained. The gelatinolytic activities were detected as transparent bands against stained gelatin background. MMPs were identified by their molecular weights compared to standards. To measure band intensities densitometric analysis was carried out using TotalLab Quant ${ }^{\circledR}$. Activities were corrected by protein content and data are expressed as arbitrary densitometric units (ADU)/ $\mu \mathrm{g}$ of proteins.

\section{Neutrophil infiltration}

Liver neutrophil infiltration was quantified by measuring myeloperoxidase (MPO) activity as described previously(5). Briefly, liver homogenate was prepared in $50 \mathrm{mM}$ phosphate buffer ( $\mathrm{pH}$ 6.0) containing $0.5 \%$ cetyltrimethylammonium bromide (CTAB; Sigma-Aldrich Co., St. Louis, MO, EUA), sonicated for $10 \mathrm{~s}$ and freeze-thawed three times, and centrifuged at $14,000 \mathrm{rpm}$ for $15 \mathrm{~min}$ at $4^{\circ} \mathrm{C}$. The supernatant was added to o-dianisidine dihydrochloride $2 \mathrm{mg} / \mathrm{mL}$ (Sigma-Aldrich Co., St. Louis, MO, EUA) and hydrogen peroxide $\left(\mathrm{H}_{2} \mathrm{O}_{2} 10 \mathrm{mM}\right)$, and the change in absorbance at $460 \mathrm{~nm}$ was measured. MPO activity was calculated using the molar extinction coefficient $\left(\varepsilon=11.48 \mathrm{mM}^{-1} \cdot \mathrm{cm}^{-1}\right)^{(11)}$. One unit of MPO was defined as the amount that degraded $1 \mu \mathrm{mol}$ of hydrogen peroxide per minute at $25^{\circ} \mathrm{C}$. Results are expressed as specific activity (mUE/mg protein).

\section{Glycosaminoglycan extraction and analysis}

GAGs were extracted by proteolysis of tissue samples with papain $(1 \mathrm{mg} / \mathrm{mL}$ in $0.05 \mathrm{M}$ phosphate-cysteine buffer $\mathrm{pH} 6.5$ and $20 \mathrm{mM}$ EDTA $-1 \mathrm{~mL} / 100 \mathrm{mg}$ of tissue) and trichloroacetic acid and ethanol precipitation as previously described ${ }^{(4)}$. Samples were purified by anionic ion-exchange chromatography on $Q$-sepharose fast flow and submitted to agarose gel electrophoresis $(5 \mu \mathrm{L})$ in $0.05 \mathrm{M}$ 1,3-diaminopropane-acetate buffer (PDA), $\mathrm{pH} 9.0^{(9)}$. After fixation with $\mathrm{CTAB}$, drying and toluidine blue staining, GAGs were 
quantified by densitometry of gel slabs (Scanner Epson Expression 1680, model G780B, Helena Laboratories). Measure of bands intensities was carried out using Quick Scan $2000^{\circ}$ software (Quick Scan 2000 WIN version 1.14/00, Copyright 2001, Helena Laboratories).

\section{Statistical analysis}

Statistical analysis were performed using GraphPadPrism 6.01 for Windows. Normality of the data was verified by the Shapiro-Wilk test, the comparison of data distributed on the curve of normality was performed by one-way ANOVA with Tukey's multiple comparison post-hoc test. Data are expressed as mean \pm standard error of the mean (SEM).

\section{RESULTS}

After surgery, we observed weight gain for animals of both groups (Sham and BDL) after 7 or 14 days of experi- ment. Although initially, we have noticed a significant weight loss for induced 2 days group animals ( 7-fold; $P=0.0257$ ) (Figure 1A). BDL rats presented higher liver weight with increasing values for $7(P=0.0305)$ and $14(P<0.0001)$ days groups (Figure 1A and B).

To access cholestatic process installation, serum levels of DB, ALT, AST, GGT, Alk-P and globulins were determined in both Sham and BDL groups (Figure 2). All BDL animals presented high DB levels $(P<0.0001)$ (Figure 2A). ALT activity was also higher on induced animals reaching maximum levels on 2 days group $(P<0.0001)$ and lower but rising values on 7 and 14 days groups. AST increased on every group when compared to Sham-operated animals, with highest activities on 2 days $(P<0.0001)$ (Figure 2A, B). GGT, Alk-P and Globulins presented increasing values on 2, 7 and 14 days groups of BDL animals, while Sham groups remained on basal levels (Figure 2D, E and F).

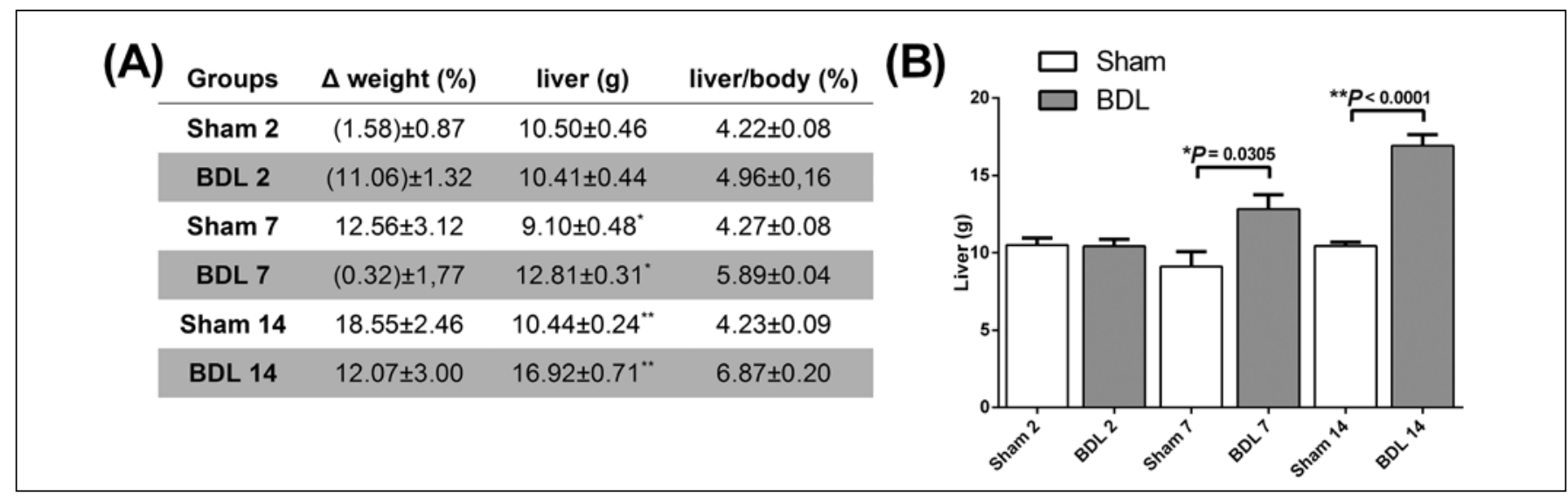

FIGURE 1. Changes on rats' liver after bile duct ligation (BDL). (A) Data description of weight variation during experiments, liver mass and liver/ body weight ratio. (B) Rats' liver weight variation $\left({ }^{*} P=0.0305,{ }^{* *} P<0.0001\right)$. Values expressed as mean \pm SEM.

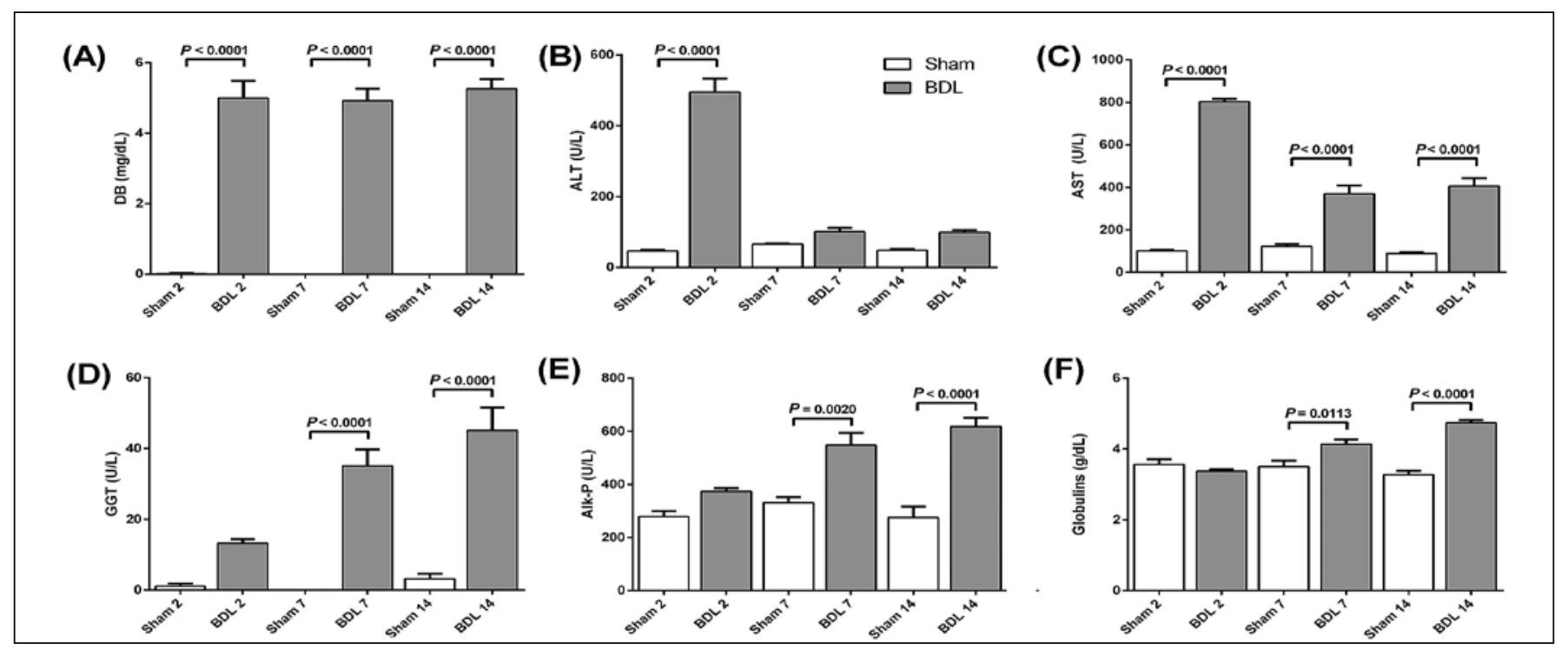

FIGURE 2. Biochemical serum parameters of liver injury. (A) Direct bilirubin (mg/dL); (B) Alanine Transaminase (U/L); (C) Aspartate Transaminase (U/L); (D) Gamma Glutamyl Transpeptidase (U/L); (E) Alkaline Phosphatase (U/L); (F) Globulins (g/dL). Values expressed as mean \pm SEM. 
Histopathological analysis of liver specimens showed increasing ductular proliferation on portal triads of BDL animals in all groups, with presence of fibrotic septum on 14 days group (Figure $3 \mathrm{~A} \mathrm{f}$ ). Morphometric measures of ductular proliferation on portal areas are shown on Figure $3 \mathrm{~B}$. It was also observed neutrophil infiltration on these tissues, confirmed by myeloperoxidase (MPO) activity, with higher levels for BDL than Sham animals on both seven $(P=0.0064)$ and $14(P=0.0002)$ days groups (Figure 3A, B).

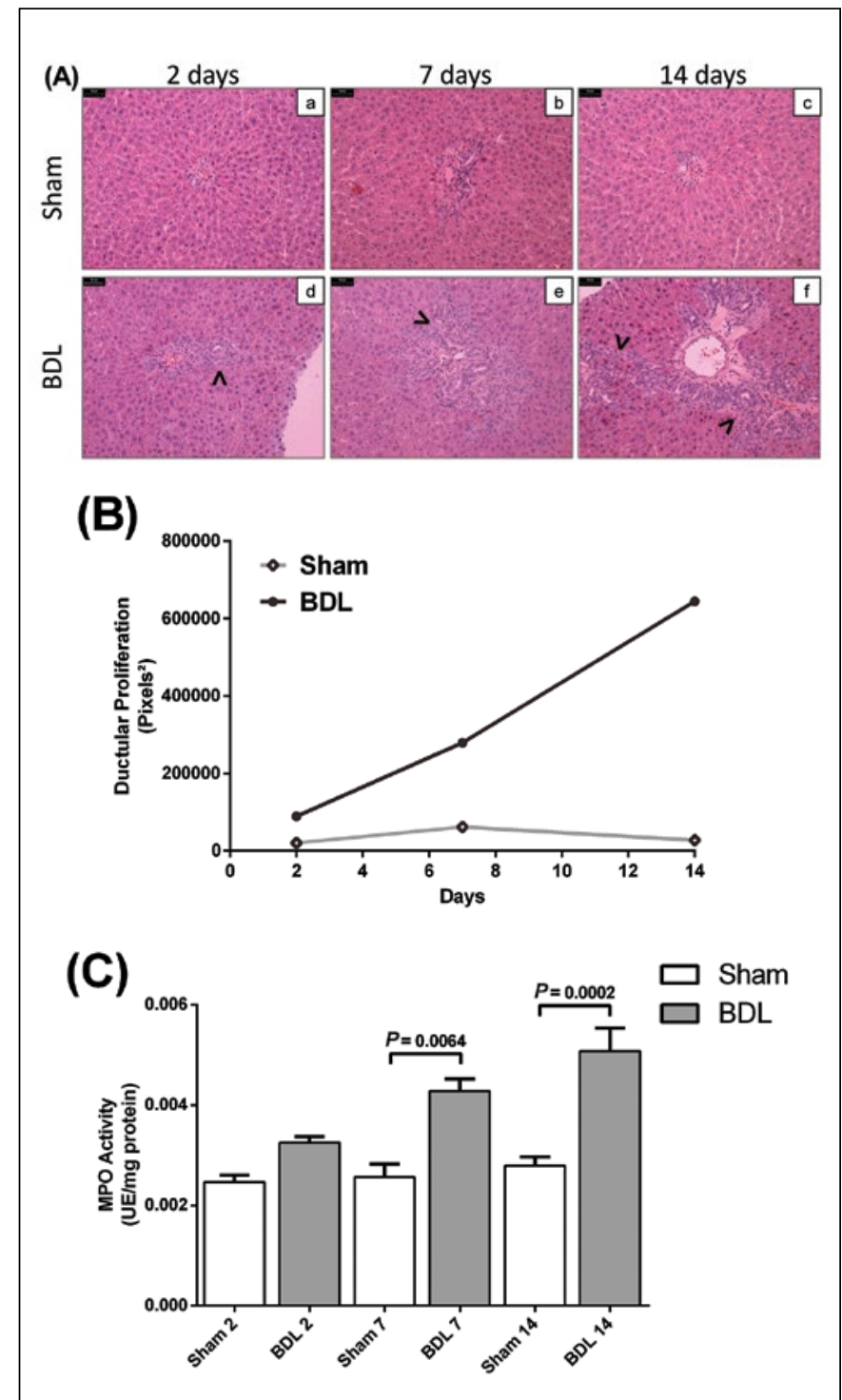

FIGURE 3. Tissue alterations on bile duct ligation (BDL) animals. (A) Histopathological changes on rats' liver (H\&E, original magnification $200 \mathrm{x}$, bars $=50 \mu \mathrm{m})$. Sham groups maintained normal parenchyma architecture $(\mathrm{a}, \mathrm{b}, \mathrm{c})$, while BDL animals presented increasing ductular proliferation on 2, 7 and 14 days groups (arrows on d, e, f), confirmed by (B) morphometric measure of portal triads. Initial injuries on tissue cause chemokines liberation leading to neutrophil infiltrate, confirmed by $(\mathrm{C})$ myeloperoxidase (MPO) activity on liver homogenates, increasing on BDL animals from 2, 7 and 14 days groups. Values expressed as mean \pm SEM.
Cholestasis induced a rise on MMPs activities on liver homogenates. MMP-2 activity presented increasing values on $7(P=0.0023)$ and $14(P=0.0003)$ days groups while Sham activities remained constant (Figure 4A). BDL reflected even on pro MMP-2 levels, with higher activities on zymograms of induced animals on 14 days group $(P=0.0677$; Figure 4B). It was also observed an increasing MMP-9 activity on BDL samples on each experimental group reaching approximately 4 -fold the control on 14 days group $(P<0.0001$; Figure $4 \mathrm{C})$.

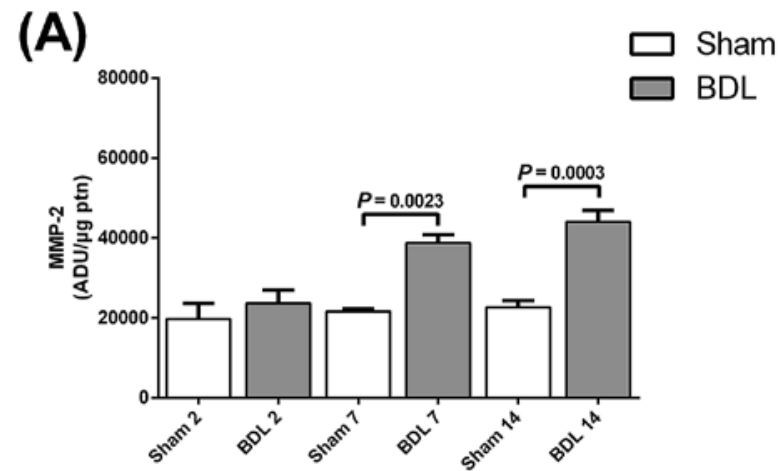

(B)

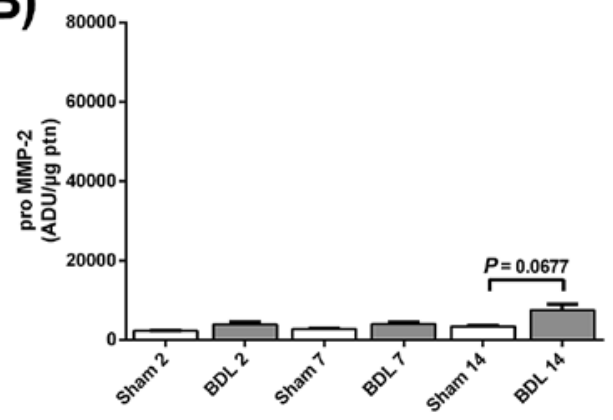

(C)

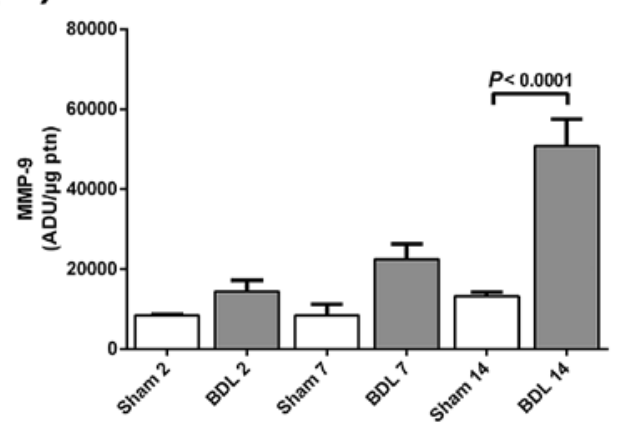

FIGURE 4. Matrix metalloproteinases (MMPs) activities on liver homogenates. Homogenates $(10 \mu \mathrm{g}$ of protein) were submitted to SDS-PAGE $(10 \%)$ with substrate (gelatin $2 \mathrm{mg} / \mathrm{mL}$ ). After incubation and Coomassie Blue staining, activities of (A) MMP-2, (B) pro MMP-2 and (C) MMP-9 were quantified by bands densitometry on gel slabs. Values expressed as mean \pm SEM. 
Dermatan sulfate (DS) and heparan sulfate (HS) are the major GAG found in the liver with smaller amounts of chondroitin sulfate (CS) (Figure 5A). BDL animals showed higher hepatic content of DS and HS than Sham-operated ones (Figure 5C, D) causing an elevation on total GAG content (Figure 5E).

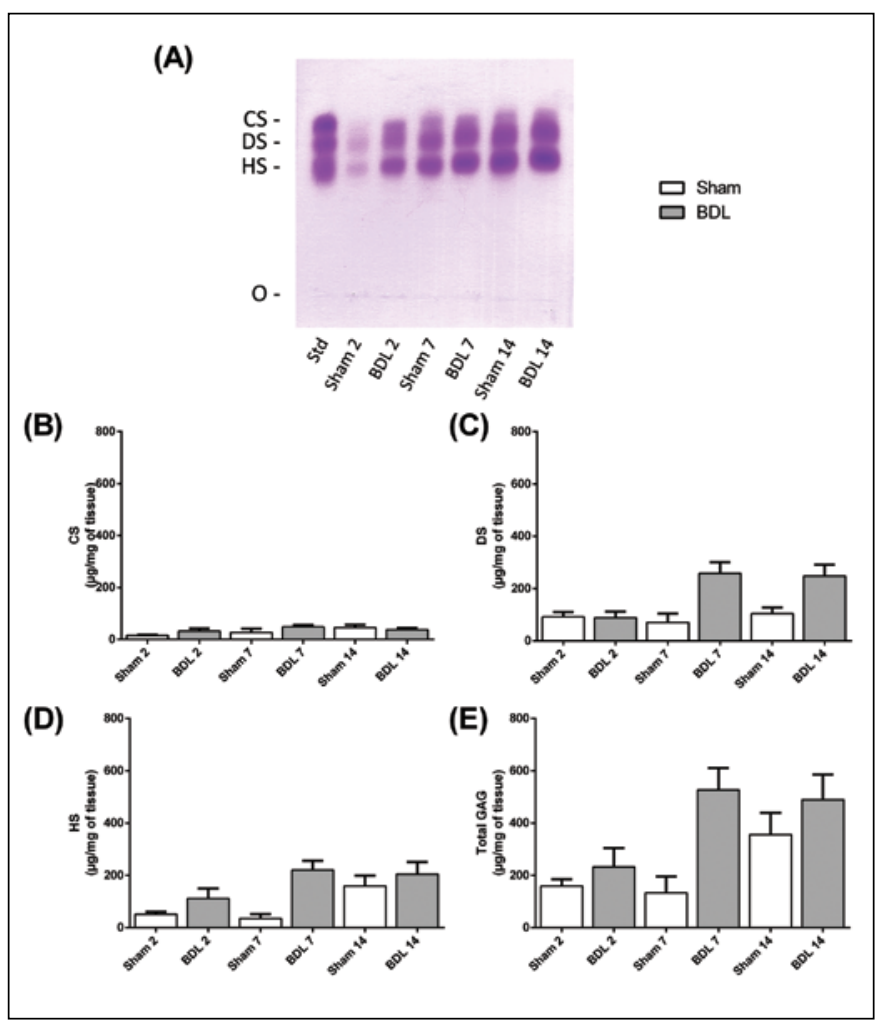

FIGURE 5. Glycosaminoglycans content on cholestatic liver. After proteolytic digestion of the tissue and purification by anionic ion exchange chromatography ( $Q$-sepharose fast flow) liver samples were submitted to (A) agarose gel electrophoresis on PDA buffer $(\mathrm{pH}=9.0)$. Samples from Sham animals are $2 \mathrm{x}$ concentrated (B) Chondroitin sulfate $(\mu \mathrm{g} / \mathrm{mg}$ of tissue); (C) Dermatan sulfate ( $\mu \mathrm{g} / \mathrm{mg}$ of tissue); (D) Heparan sulfate ( $\mu \mathrm{g} /$ $\mathrm{mg}$ of tissue); (D) Total GAG content ( $\mu \mathrm{g} / \mathrm{mg}$ of tissue). Bile duct ligation (BDL) animals presented increasing on DS and HS content reflecting ECM production and ductular proliferation due to parenchyma depletion. Values expressed as mean \pm SEM.

\section{DISCUSSION}

Animal models have been widely used to comprehend mechanisms underlying acute and chronic liver injury ${ }^{(20,30,31)}$. In our study, we analyzed early stages of BDL on rats' liver cells and ECM in order to understand effects of extrahepatic cholestasis and its pathological changes. During cholestasis bile duct walls become thin and stiff and hepatic gap junctions disappear with formation of large crater-like fenestrae in ductular epithelium and development of focal necrosis, causing leakage of toxic substances such as hydrophobic bile acids with parenchymal damage and induction of liver injury ${ }^{(16,22)}$.
Rats submitted to early extrahepatic cholestasis presented weight loss on 2 days group when compared to Sham-operated, what might have happened because of most stressing surgical procedure (Figure 1A). Increasing on liver weight of BDL animals (7 and 14 days groups) may be due to tissue's hyperplasia, ductular proliferation, edema and/or increased hepatic ECM (Figure 1B) $)^{(2,14,15)}$.

Raise on DB levels of cholestatic rats (Figure 2A) is the first sign of bile retention and responsible for primary injuries on liver ${ }^{(10)}$. Bile salts damage hepatocytes membranes, what changes cellular permeability causing a rise on serum aminotransferases' levels. BDL animals showed increasing activity in both enzymes: ALT levels raised on 2 days group when compared to Sham-operated animals, showing acute response to injuries, most probably due to surgery stress, while AST activity showed increasing pattern on 7 and 14 days groups. These changes, so as in globulins levels, indicate lesions on liver parenchyma after ligation. Significantly increased GGT and Alk-P activities point to biliary injury due to severe obstructive cholestasis, because of damage on epithelial cells of bile ducts (Figure 2C, D) ${ }^{(40)}$.

We observed classic histopathological features on animals submitted to BDL, with increasing substitution of liver parenchyma by epithelial bile duct cells on portal triad (Figure 3A and B). Ductular proliferation and ECM deposition are responsible for major tissue changes resulting on formation of fibrotic septum, first sign of tissue fibrosis (Figure 3A f ${ }^{(8,23)}$. Apoptotic bodies of hepatocytes activate Kupffer cells, which secrete cytokines and chemokines perpetuating the signal by recruiting leucocytes to the injury sites, among them neutrophils, which is confirmed by MPO activity, enzyme present on azurophilic granules of these cells, that showed increased on $7(P=0.0064)$ and $14(P=0.0002)$ days groups of BDL animals (Figure $3 C)^{(13,24)}$.

Pro-inflammatory and fibrogenic mediators secreted led to early changes on ECM and consequent activation of hepatic stellate cells (HSCs), vitamin A storing cells activated to a profibrogenic myofibroblastic form responsible for breaking and renovation of ECM in substitution to liver parenchyma. Active HSC controls expression and regulation of MMPs and its inhibitors (TIMPs) ${ }^{(1,25)}$.

BDL rats of 14 days group presented higher MMP-2 activity than control (Figure 4B) maybe due to HSCs activation, with previous evidence of increasing expression and activity of this enzyme on chronic liver diseases and cirrhosis. This group also presented augmentation on pro MMP-2 activity, what may be a sign of rising on enzyme expression (Figure 4A), as demonstrated on hepatic fibrosis induced by $\mathrm{CCl}_{4}{ }^{(38)}$. MMP-9 activity was also higher for BDL animals (Figure 4C), what might be related to inflammatory process of the liver, since this enzyme is usually co-located to Kupffer cells ${ }^{(1,41)}$.

Activation of HSC with rising on MMPs activities result on ECM remodeling, causing major changes on its constitution. Previous authors cited changes on collagen types I, III, IV, V, and VI, and many non collagenous components, including fibronectin, laminin, tenascin, undulin, and entactin on fibrotic 
livers ${ }^{(36)}$, but GAGs content alterations was not described. As in our study, previous works show that the main GAGs found on liver are dermatan sulfate and heparan sulfate with smaller amounts of chondroitin sulfate ${ }^{(17,19,32,33)}$. Cholestasis resulted on a great rise of dermatan sulfate and heparan sulfate content (Figure 5). DS is mainly found on ECM proteoglycans (PGs) reflecting its degradation and reassembly, while HS is characteristic of cell surface PGs, reflecting cellular proliferation, in this case ductular epithelial cells.

Net deposition that occurs during hepatic fibrosis has generated a great deal of interest in liver's ECM changes. Results of our study are in agreement with previous reports indicating marked alterations in MMPs activity and tissue injury on early stages of extrahepatic cholestasis. Nevertheless, we have also demonstrated an important modification on ECM content, suggesting that initial destruction of this structure leads to further substitution of liver parenchyma.

\section{CONCLUSIONS}

We have shown that important information can be gained by analyzing ECM to access liver's injury. The whole process of tissue depletion after bile salts accumulation ends up to MMPs activity, which leads to ECM renovation and expansion that causes fibrosis of the liver with major changes on GAGs content.

Guedes PLR, Castañon MCMN, Nagaoka MR, Aguiar JAK. Aumento de glicosaminoglicanos e metaloproteinases 2 e 9 na matriz extracelular de fígado em estágios iniciais de colestase extra-hepática. Arq Gastroenterol. 2014,51(4):309-15.

RESUMO - Contexto - Colestase produz lesão hepatocelular, infiltração leucocitária, proliferação de células ductulares e fibrose do parênquima hepático por matriz extracelular. Objetivo - Analisar os efeitos da ligação do ducto biliar sobre conteúdo de glicosaminoglicanos e atividade de metaloproteinases de matriz (MMP). Métodos - Animais (6-8 semanas; $\mathrm{n}$ = 40) foram eutanasiados 2, 7 ou 14 dias após ligação do ducto biliar ou falsa ligação. A evolução da doença foi analisada por peso corporal e do fígado, concentrações séricas de bilirrubina direta, globulinas, gama glutamil transpeptidase (GGT), fosfatase alcalina (Alk-P), alanina e aspartato aminotransfesases (ALT e AST), alterações teciduais de mieloperoxidase e metaloproteinases (MMP-9, pro MMP-2 e MMP-2), histopatologia e conteúdo de glicosaminoglicanos. Resultados - A colestase causou dano celular com elevação dos níveis séricos de globulinas, GGT, Alk-P, ALT e AST. Houve também infiltração leucocitária observada pelo aumento na atividade de mieloperoxidase nos grupos $7(P=0,0064)$ e 14 dias $(P=0,0002)$ o que leva ao aumento das lesões no tecido. Ligação do ducto biliar aumentou as atividades de pro MMP-2 $(P=0,0677)$, MMP-2 $(P=0,0003)$ e MMP-9 $(P<0,0001)$ aos 14 dias indicando remodelamento da matriz e estabelecimento de processo inflamatório. Animais com ligação do ducto biliar mostraram um aumento do conteúdo de dermatam sulfato e/ou heparam sulfato refletindo a produção de matriz extracelular e aumento de mitose devido a depleção do parênquima hepático. Conclusão - Colestase causou várias mudanças no parênquima hepático de ratos, bem como em sua matriz extracelular, com importantes alterações na atividade de MMPs e no conteúdo de glicosaminoglicanos.

DESCRITORES - Colestase extra-hepática. Glicosaminoglicanas. Metaloproteinases de matriz. 


\section{REFERENCES}

1. Arthur MJ. Fibrogenesis II. Metalloproteinases and their inhibitors in liver fibrosis Am J Physiol Gastrointest Liver Physiol. 2000;279:G245-9.

2. Belmiro CL, Goncalves RG, Kozlowski EO, Werneck AF, Takyia CM, Leite-Jr M, Pavão MS. Dermatan sulfate reduces monocyte chemoattractant protein 1 and TGF-beta production, as well as macrophage recruitment and myofibroblast accumulation in mice with unilateral ureteral obstruction. Braz J Med Biol Res. 2011;44:624-33.

3. Berger ML, Bhatt H, Combes B, Estabrook RW. CCl4-induced toxicity in isolated hepatocytes: the importance of direct solvent injury. Hepatology. 1986;6:36-45.

4. Berto AG, Sampaio LO, Franco CR, Cesar RM Jr., Michelacci YM. A comparative analysis of structure and spatial distribution of decorin in human leiomyoma and normal myometrium. Biochim Biophys Acta. 2003;1619:98-112.

5. Bradley PP, Priebat DA, Christensen RD, Rothstein G. Measurement of cutaneous inflammation: estimation of neutrophil content with an enzyme marker. The Journal of investigative dermatology. 1982;78:206-9.

6. Departamento de Informática do Sistema Único de Saúde [Internet]. Brasília [cited 2013 Jun 10]. Available from: <http://www2.datasus.gov.br/>

7. Chen JC, Chen HM, Shyr MH, Fan LL, Chi TY, Chi CP, Chen MF. Selective inhibition of inducible nitric oxide in ischemia-reperfusion of rat small intestine. J Formos Med Assoc. 2000;99:213-8.

8. Desmouliere A, Darby I, Costa AM, Raccurt M, Tuchweber B, Sommer P, Gabbiani G. Extracellular matrix deposition, lysyl oxidase expression, and myofibroblastic differentiation during the initial stages of cholestatic fibrosis in the rat. Lab Invest. 1997;76:765-78.

9. Dietrich CP, Dietrich SM. Electrophoretic behaviour of acidic mucopolysaccharides in diamine buffers. Anal Biochem. 1976;70:645-7.

10. Faubion WA, Guicciardi ME, Miyoshi H, Bronk SF, Roberts PJ, Svingen PA, et al. Toxic bile salts induce rodent hepatocyte apoptosis via direct activation of Fas. J Clin Invest. 1999;103:137-45.

11. Fietz S, Bondzio A, Moschos A, Hertsch B, Einspanier R. Measurement of equine myeloperoxidase (MPO) activity in synovial fluid by a modified MPO assay and evaluation of joint diseases - an initial case study. Res Vet Sci. 2008;84:347-53.

12. Greim H, Trulzsch D, Roboz J, Dressler K, Czygan P, Hutterer F, et al. Mechanism of cholestasis. 5. Bile acids in normal rat livers and in those after bile duct ligation. Gastroenterology. 1972;63:837-45.

13. Gujral JS, Farhood A, Bajt ML, Jaeschke H. Neutrophils aggravate acute liver injury during obstructive cholestasis in bile duct-ligated mice. Hepatology. 2003;38:355-63.

14. Gulubova MV. Ultrastructural sinusoidal changes in extrahepatic cholestasis Light and electron microscopic immunohistochemical localization of collagen type III and type IV. Acta Histochem. 1996;98:271-83.

15. Haveman J, James J, Geerdink A. Collagen content in rat liver after experimentally induced cholestasis followed by choledochojejunostomy and X-irradiation. Liver. 1996; 16:195-200.

16. Jaeschke H. Inflammation in response to hepatocellular apoptosis. Hepatology. 2002;35:964-6

17. Kawakami H, Terayama H. Liver plasma membranes and proteoglycan prepared therefrom inhibit the growth of hepatoma cells in vitro. Biochim Biophys Acta. 1981;646:161-8.

18. Kim KH, Kim HC, Hwang MY, Oh HK, Lee TS, Chang YC, et al. The antifibrotic effect of TGF-betal siRNAs in murine model of liver cirrhosis. Biochem Biophys Res Commun. 2006;343:1072-8.

19. Koide N, Shinji T, Tanabe T, Asano K, Kawaguchi M, Sakaguchi K, et al. Continued high albumin production by multicellular spheroids of adult rat hepatocytes formed in the presence of liver-derived proteoglycans. Biochem Biophys Res Commun. 1989; 161:385-91.

20. Kouyoumdjian M, Nagaoka MR, Borges DR. Kallikrein-kinin system in hepatic experimental models. Peptides. 2005;26:1301-7.

21. Kwo P, Patel T, Bronk SF, Gores GJ. Nuclear serine protease activity contributes to bile acid-induced apoptosis in hepatocytes. Am J Physiol. 1995;268:G613-21.
22. Lawson JA, Fisher MA, Simmons CA, Farhood A, Jaeschke H. Parenchymal cell apoptosis as a signal for sinusoidal sequestration and transendothelial migration of neutrophils in murine models of endotoxin and Fas-antibody-induced liver injury. Hepatology. 1998;28:761-7.

23. Li MK, Crawford JM. The pathology of cholestasis. Seminars in liver disease. 2004;24:21-42

24. Liu TZ, Lee KT, Chern CL, Cheng JT, Stern A, Tsai LY. Free radical-triggered hepatic injury of experimental obstructive jaundice of rats involves overproduction of proinflammatory cytokines and enhanced activation of nuclear factor kappaB. Ann Clin Lab Sci. 2001;31:383-90.

25. Lotersztajn S, Julien B, Teixeira-Clerc F, Grenard P, Mallat A. Hepatic fibrosis: molecular mechanisms and drug targets. Annu Rev Pharmacol Toxicol. 2005;45:605-28.

26. Miura RO, Yamagata S, Miura Y, Harada T, Yamagata T. Analysis of glycosaminoglycan-degrading enzymes by substrate gel electrophoresis (zymography). Anal Biochem. 1995;225:333-40.

27. Muriel P. Role of free radicals in liver diseases. Hepatol Int. 2009;3:526-36.

28. Muriel P, Moreno MG, Hernandez Mdel C, Chavez E, Alcantar LK. Resolution of liver fibrosis in chronic $\mathrm{CCl} 4$ administration in the rat after discontinuation of treatment: effect of silymarin, silibinin, colchicine and trimethylcolchicinic acid Basic Clin Pharmacol Toxicol. 2005;96:375-80.

29. Muriel P, Mourelle M. The role of membrane composition in ATPase activities of cirrhotic rat liver: effect of silymarin. J Appl Toxicol. 1990;10:281-4.

30. Nagaoka MR, Gomiero L, Teixeira FO, Agostino FG, Pouza JE, Mimary P, et al Is the expression of kinin $\mathrm{B}(1)$ receptor related to intrahepatic vascular response? Biochim Biophys Acta. 2006;1760:1831-6.

31. Nagaoka MR, Le Sueur-Maluf L, Aguiar O Jr., Castro GM, Spadari-Bratfisch $\mathrm{RC}$, Ribeiro DA. Differential response related to genotoxicity in multiple organs of cirrhotic rats. Hepatol Int. 2011;5:740-6.

32. Ohnishi T, Ohshima E, Ohtsuka M. Effect of liver cell coat acid mucopolysaccharide on the appearance of density-dependent inhibition in hepatoma cell growth Exp Cell Res. 1975;93:136-42.

33. Otsu K, Kato S, Ohtake K, Akamatsu N. Alteration of rat liver proteoglycans during regeneration. Arch Biochem Biophys. 1992;294:544-9.

34. Patel T, Bronk SF, Gores GJ. Increases of intracellular magnesium promote glycodeoxycholate-induced apoptosis in rat hepatocytes. J Clin Invest. 1994;94 2183-92.

35. Schmucker DL, Ohta M, Kanai S, Sato Y, Kitani K. Hepatic injury induced by bile salts: correlation between biochemical and morphological events. Hepatology. 1990;12:1216-21.

36. Schuppan D. Structure of the extracellular matrix in normal and fibrotic liver: collagens and glycoproteins. Semin Liver Dis. 1990;10:1-10.

37. Shapiro SD, Kelley D, Kobayashi D. Measurement of metalloproteinases. Methods Mol Med. 2001;56:383-90.

38. Takahara T, Furui K, Funaki J, Nakayama Y, Itoh H, Miyabayashi C, et al Increased expression of matrix metalloproteinase-II in experimental liver fibrosis in rats. Hepatology. 1995;21:787-95.

39. Tuchweber B, Desmouliere A, Bochaton-Piallat ML, Rubbia-Brandt L, Gabbian G. Proliferation and phenotypic modulation of portal fibroblasts in the early stages of cholestatic fibrosis in the rat. Laboratory investigation; a journal of technica methods and pathology. 1996;74:265-78.

40. Wen YA, Liu D, Zhou QY, Huang SF, Luo P, Xiang Y, et al. Biliary intervention aggravates cholestatic liver injury, and induces hepatic inflammation, proliferation and fibrogenesis in BDL mice. Exp Toxicol Pathol. 2011;63:277-84

41. Winwood PJ, Schuppan D, Iredale JP, Kawser CA, Docherty AJ, Arthur MJ Kupffer cell-derived 95-kd type IV collagenase/gelatinase B: characterization and expression in cultured cells. Hepatology. 1995;22:304-15.

42. Wynn TA. Cellular and molecular mechanisms of fibrosis. J Pathol. 2008;214 $199-210$ 